\title{
PEDICLE MORPHOLOGY IN SCOLIOSIS: CLASSIFICATION AGREEMENT FOR PRE-OPERATIVE EVALUATION
}

\author{
MORFOLOGIA DO PEDÍCULO NA ESCOLIOSE: CONCORDÂNCIA NA CLASSIFICAÇÃO PARA \\ AVALIAÇÃO PRÉ-OPERATÓRIA
}

\section{MORFOLOGÍA DEL PEDÍCULO EN LA ESCOLIOSIS: CONCORDANCIA DE CLASIFICACIÓN PARA EVALUACIÓN PREQUIRÚRGICA}

\author{
Luiz Eduardo Pereira Costa Assis de Almeida, ${ }^{1,2}$ Luis Eduardo Carelu Teixeira da Silva, ${ }^{1,2,3}$ Caloue Jauhar de Castro, ${ }^{1,2}$ Giulana Vasconcelos de Souza Fonseca, \\ Robson TelXeira VitaL, 1 Márcia Maria Rodrigues Jardim ${ }^{3}$
}

\author{
1. Instituto Nacional de Traumatologia e Ortopedia (INTO), Rio de Janeiro, RJ, Brazil. \\ 2. Instituto da Coluna Vertebral do Rio de Janeiro (INCOL), Rio de Janeiro, RJ, Brazil. \\ 3. Universidade Federal do Estado do Rio de Janeiro, Postgraduate Program in Neurology (PPGNEURO- UNIRIO), Rio de Janeiro, RJ, Brazil.
}

4. Instituto de Pesquisas Biomédicas do Hospital Naval Marcílio Dias (IPB-HNMD), Rio de Janeiro, RJ, Brazil.

\begin{abstract}
Objectives: Although Watanabe morphological classification is well known, there is no consensus of its use among spine surgeons. We propose an analysis of the Watanabe classification by three observers, one senior and two recently graduated orthopedic spine surgeons, and its applicability in pre-operative evaluation. Methods: An intraobserver and interobserver analysis of the classifications of 937 thoracic pedicles among 55 scoliosis patients treated surgically in two institutions. The average age at time of surgery was 16.3 years (10-50 years). The etiologies of the scoliosis were: idiopathic ( $n=47)$, congenital ( $n=4)$, syndromic $(n=3)$ and neuromuscular $(n=1)$. The mean Cobb angle was 67 degrees $\left(41-120^{\circ}\right)$. The evaluation of the thoracic pedicle was performed using pre-operative CT images. Results: A total of 937 pedicles were classified by three observers with percentages of $47.5 \%$ type A, 28.6\% type B, $17.1 \%$ type $\mathrm{C}$ and $6.9 \%$ type $\mathrm{D}$ for the total pedicles, convex and concave. Intraobserver agreement was fair to almost perfect (kappa 0.34 to 0.92$)$ and interobserver agreement was fair to moderate (kappa 0.33 to 0.59 ) with statistical significance of $p<0.001$. Conclusion: Watanabe classification remains a good method for predicting intraoperative difficulties, and has better agreement as the surgeon becomes more experienced. Level of evidence II; Prognostic Studies.
\end{abstract}

Keywords: Pedicle Screws; Morphology; Scoliosis.

\section{RESUMO}

Objetivo: A classificação morfológica dos pedículos descrita por Watanabe, apesar de bem conhecida, não é consenso entre os cirurgiões de coluna. Propomos uma análise da classificação por três obsenvadores, um sênior e dois cirurgiões de coluna recém-graduados, e sua aplicabilidade na avaliação pré-operatória. Métodos: Foi realizada uma análise intraobsenvador e interobservador das classificações de Watanabe de 937 pedículos em 55 pacientes com escoliose, tratados cirurgicamente em duas instituições. A média de idade no momento da cirurgia foi de 16,3 anos (10 a 50 anos). As etiologias da escoliose foram: idiopática $(n=47)$, congênita $(n=4)$, sindrômica $(n=3)$ e neuromuscular $(n=1)$. 0 ângulo médio de Cobb foi de 67 graus $\left(41^{\circ}\right.$ a $120^{\circ}$. A avaliação dos pedículos torácicos foi realizada com imagens pré-operatórias de tomografia computadorizada. Resultados: Três observadores classificaram 937 pedículos côncavos e convexos, evidenciando 47,5\% do tipo A; 28,6\% do tipo B; 17,1\% do tipo C e 6.9\% do tipo D. A concordância intraobservador foi de razoável a quase perfeita (kappa 0,34 a 0,92) e concordância interobservador foi de razoável a moderada (kappa 0,33 a 0,59), com significância estatística de $p<0,001$. Conclusões: A classificação de Watanabe pode ser considerada um bom método para prever dificuldades intraoperatórias e apresenta melhor concordância à medida que o cirurgião se torna mais experiente. Nível de Evidência II; Estudos Prognósticos.

Descritores: Parafusos Pediculares; Morfologia; Escoliose.

\section{RESUMEN}

Objetivo: La clasificación morfológica de los pedículos descrita por Watanabe, a pesar de ser bien conocida, no es consenso entre los cirujanos de columna. Proponemos un análisis de la clasificación por 3 obsenvadores, un sénior y dos cirujanos de columna recién graduados, y su aplicabilidad en la evaluación prequirúrgica. Métodos: Fue realizado un análisis intraobsenador e interobservador de las clasificaciones de Watanabe de 937 pedículos en 55 pacientes con escoliosis, tratados quirúrgicamente en dos instituciones. El promedio de edad en el momento de la cirugía fue de 16,3 años (10-50 años). Las etiologías de la escoliosis fueron: idiopática $(n=47)$, congénita $(n=4)$, sindrómica $(n=3)$ y neuromuscular $(n=1)$. El ángulo promedio de Cobb fue de 67 grados $\left(41^{\circ}\right.$ a $\left.120^{\circ}\right)$. La evaluación de los pedículos torácicos fue realizada con imágenes prequirúrgicas de tomografía computada. Resultados: Tres observadores clasificaron 937 pedículos cóncavos y convexos, evidenciando 47,5\% tipo A, 28,6\% tipo B, 17,1\% tipo C y 6,9\% tipo D. La concordancia intraobsenador fue de razonable a casi perfecta (kappa 0,34 a 0,92)y la concordancia interobsenador fue de razonable a moderada (kappa 0,33 a 0,59) con una significancia estadística de $p<0,001$. Conclusiones: La clasificación de Watanabe puede ser considerada un buen método para prever dificultades intraquirúrgicas y presenta mejor concordancia a medida que el cirujano se vuelve más experimentado. Nivel de Evidencia II; Estudios Pronósticos.

Descriptores: Tornillos Pediculares; Morfologia; Escoliosis. 


\section{INTRODUCTION}

Scoliosis is a three-dimensional deformity of the spine, with deviation on the coronal plane, lordosis or kyphosis on the sagittal plane and axial rotation.

This complex anatomy makes it one of the most challenging pathologies in spine surgery. There are a variety of surgical treatments for this pathology, including different methods of instrumentation, such as sublaminar wires, hooks and pedicle screws.

Thoracic pedicle screw instrumentation has better corrective ability than hook and sublaminar wires, ${ }^{1-3}$ and a higher pullout strength. ${ }^{4}$ Despite their advantages, thoracic pedicles are smaller ${ }^{5}$ and thinner than lumbar pedicles, more dysplastic in patients with scoliosis, especially on the concave side, apex, and proximal thoracic segment, and are sometimes dangerous to instrument. ${ }^{6-11}$

Screw misplacement can have catastrophic consequences, jeopardizing the vascular structures, the spinal cord, and the correction strength. ${ }^{12,13}$ To minimize the risk, it is advisable to have good pre-operative planning, with pedicle morphological analysis by pre-operative computer tomography (CT) scan.

Watanabe ${ }^{14}$ described one of the most popular pedicle classifications, which is based on the bone anatomy during probe insertion and confirmed by CT imaging. Spine surgeons can use radiological Watanabe classification to predict difficulties and perform strategies before surgery, and to help them decide whether to use screw instrumentation or another alternative instrumentation method for each level.

The Watanabe classification divides pedicles in four types: A- large cancellous pedicle; B- small cancellous pedicle; C- cortical channel; D- slit/absent channel.

Other authors ${ }^{15}$ described an objective classification based on CT in which the surgeon has to measure the pedicle width and divide those pedicles in four types, A, B, C and D. This differs from the Watanabe classification, which is based on visual radiological analysis.

In the present study, we analyze the interobserver and intraobserver reliability of the radiological Watanabe classification, and its use.

\section{METHODS}

This is a retrospective cohort, level II, prognostic study of 55 patients with scoliosis treated in two institutions between 2016 and 2019: the Instituto Nacional de Traumatologia e Ortopedia and the Instituto da Coluna vertebral do Rio de Janeiro. Data collection was performed after an Institutional Review by an Ethics Committee in Scientific Research, under registration number C.A.A.E 70805517.4.00005273.

We analyzed 937 thoracic pedicles of 55 patients diagnosed with scoliosis: idiopathic $(n=47)$, congenital $(n=4)$, neuromuscular $(n=1)$ and syndromic $(n=3)$.

Some characteristics of the selected patients are as follows: Age (10-50 years), Sex (11 Male; 44 Female), scoliosis etiology, Cobb angle (41 - 120 degrees), and whether the pedicle was separated by the convex or concave side. The study population had a median age of 16.3 years and a median Cobb angle of 67 degrees. The patients were divided into three groups: 21 patients with curves of $40-59^{\circ}, 23$ with curves of $60-79^{\circ}$ and 11 with curves greater than $80^{\circ}$.

Preoperative CT of the thoracic pedicles is our standard of care, and was used in earlier years to assess morphology and create a surgery plan. The thoracic pedicles were sliced in the axial plane into thin sections, at the pedicle isthmus, by Multi-Slice CT with volumetric acquisition of 0.5 to 1.25. The images were printed, or presented in the form of PowerPoint slides.

To minimize radiological exposure, the CT scan was carried out only of the thoracic vertebrae for which instrumentation was planned. Therefore, the number of pedicles was not equivalent to the number in the entire thoracic spine.

Those pedicles were reviewed in two rounds by three observers: a senior spine surgeon and two spine surgeons with two years of experience. Each spine surgeon was blinded to previous evaluations, or those of the other spine surgeons.

For the senior surgeon, the two rounds were performed from the first patient of the study until the last one, at intervals of 3 years to one month, and for the younger surgeons, the evaluations were performed at intervals of four weeks.

All the pedicles were classified by all the observers following the radiological Watanabe criteria, in a two round classification, and then transcribed to an excel spreadsheet containing all the characteristics mentioned above. (Figure 1)

All the pedicles that had questionable images, raising doubt, were excluded individually by each observer.

The statistical analysis was performed to assess intraobserver and interobserver classification agreement by the Cohen's Ka$\mathrm{ppa}^{16-18}$ method, with statistical significance of $5 \%(\mathrm{p}<0.05)$.

The kappa coefficient is used to describe the agreement between two or more observers when performing a nominal or numerical evaluation of the same sample. The Kappa interpretation is divided in 6 types: < 0 is poor; $0-0.20$ is slight; $0.21-0.40$ is fair; $0.41-0.60$ is moderate; $0.61-0.80$ is substantial and $0.81-1$ is almost perfect.

All the analyses were performed using $\mathrm{R}$ software version 3.6.0 (Planting of a Tree).

\section{RESULTS}

Tables 1 and 2 show the frequency (n) and percentage (\%) of radiological Watanabe pedicle classification, both concave and convex, for the two rounds and the three observers.

Tables 3 and 4 show the agreement (\%), kappa statistical coefficient and the statistical significance ( $p$-value) for each pair of comparison, intraobserver and interobserver.

The agreement is interpreted according to the percentage of identical answers in the total evaluated images. For example, in table 4 , of a total of 459 pedicles, observer I and II had $71 \%$ of agreement between concave pedicles.

The intraobserver analysis did not show absolute agreement between the first and second round analyses.

The intraobserver agreement ranged from fair to almost perfect, depending on the observer.

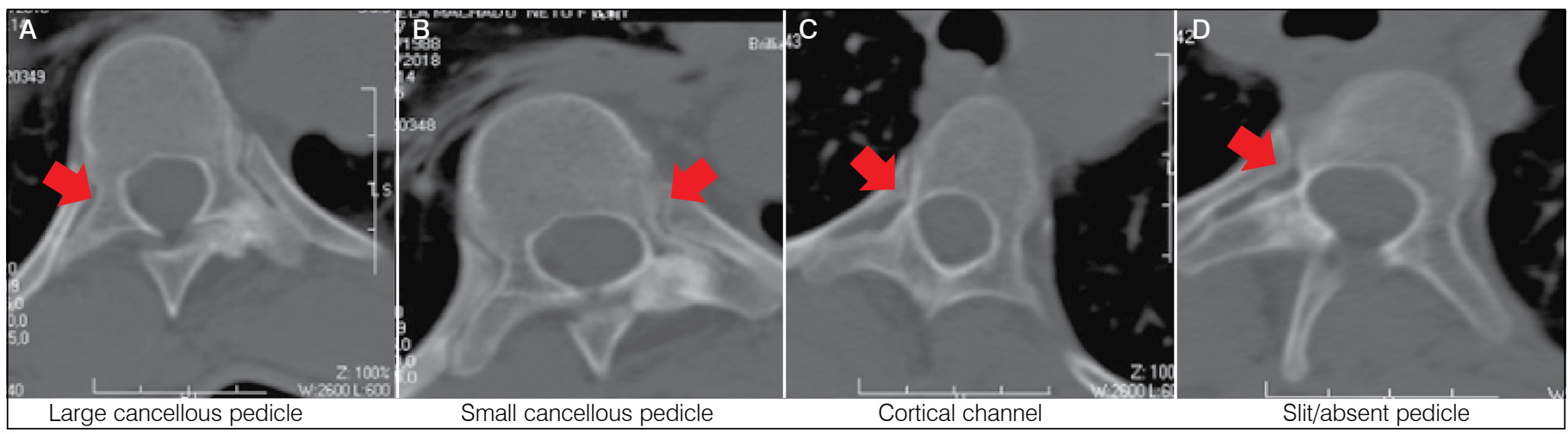

Figure 1. Radiological Watanabe Classification - Axial CT images. 
Table 1. Watanabe classification for concave pedicles

\begin{tabular}{c|c|c|c|c|c|c|c}
\hline \multicolumn{5}{|c|}{ First round } & \multicolumn{3}{c}{ Second round } \\
\hline Observer & $\mathbf{1}$ & $\mathbf{2}$ & $\mathbf{3}$ & Observer & $\mathbf{1}$ & $\mathbf{2}$ & $\mathbf{3}$ \\
\hline Classif. A & $233(49.1 \%)$ & $179(37.9 \%)$ & $207(42.7 \%)$ & Classif. A & $194(40.7 \%)$ & $157(33.1 \%)$ & $200(42 \%)$ \\
\hline Classif. B & $109(22.9 \%)$ & $144(30.5 \%)$ & $177(24.1 \%)$ & Classif. B & $140(29.4 \%)$ & $163(34.3 \%)$ & $127(26.7 \%)$ \\
\hline Classif. C & $86(18.1 \%)$ & $108(22.9 \%)$ & $104(21.4 \%)$ & Classif. C & $101(21.2 \%)$ & $122(25.7 \%)$ & $90(18.9 \%)$ \\
\hline Classif. D & $47(9.9 \%)$ & $41(8.7 \%)$ & $57(11.8 \%)$ & Classif. D & $42(8.7 \%)$ & $33(6.9 \%)$ & $59(12.4 \%)$ \\
\hline Total & $475(100 \%)$ & $472(100 \%)$ & $545(100 \%)$ & Total & $477(100 \%)$ & $475(100 \%)$ & $476(100 \%)$ \\
\hline
\end{tabular}

Classif. A, B, C and D - Radiological Watanabe pedicle morphology.

Table 2. Watanabe classification for convex pedicles.

\begin{tabular}{|c|c|c|c|c|c|c|c|}
\hline \multicolumn{4}{|c|}{ First round } & \multicolumn{4}{|c|}{ Second round } \\
\hline Observer & 1 & 2 & 3 & Observer & 1 & 2 & 3 \\
\hline Classif. A & $287(59.9 \%)$ & $250(52.9 \%)$ & $258(53.3 \%)$ & Classif. A & $282(59 \%)$ & $216(45.7 \%)$ & $256(53.9 \%)$ \\
\hline Classif. B & $114(23.8 \%)$ & $141(29.8 \%)$ & $130(26.9 \%)$ & Classif. B & $135(29.2 \%)$ & $176(37.2 \%)$ & $126(26.5 \%)$ \\
\hline Classif. C & $57(11.9 \%)$ & $62(13.1 \%)$ & $66(13.6 \%)$ & Classif. C & $50(10.5 \%)$ & $69(14.6 \%)$ & $65(13.7 \%)$ \\
\hline Classif. D & $21(4.4 \%)$ & $20(4.2 \%)$ & $30(6.2 \%)$ & Classif. D & $11(2.3 \%)$ & $12(2.5 \%)$ & $28(5.9 \%)$ \\
\hline Total & $479(100 \%)$ & $473(100 \%)$ & $484(100 \%)$ & Total & $478(100 \%)$ & $473(100 \%)$ & 475 (100\%) \\
\hline
\end{tabular}

Classif. A, B, C and D - Radiological Watanabe pedicle morphology.

Table 3. Intraobserver correlation of the Watanabe classification: First Round versus Second Round.

\begin{tabular}{c|c|c|c|c}
\hline Observer & Pedicle & N (\%) & Kappa & p \\
\hline 1 & Concave & $462(57.4 \%)$ & 0.383 & $<0.0001$ \\
\hline 1 & Convex & $467(63.2 \%)$ & 0.349 & $<0.0001$ \\
\hline 2 & Concave & $469(67.4 \%)$ & 0.538 & $<0.0001$ \\
\hline 2 & Convex & $468(68.4 \%)$ & 0.498 & $<0.0001$ \\
\hline 3 & Concave & $476(93.7 \%)$ & 0.910 & $<0.0001$ \\
\hline 3 & Convex & $475(95.2 \%)$ & 0.922 & $<0.0001$ \\
\hline
\end{tabular}

Cohen's kappa

Table 4. Interobserver analysis of the Watanabe classification.

\begin{tabular}{c|c|c|c|c|c}
\hline Round & Observer & Pedicle & N (\%) & Kappa & $\mathbf{P}^{*}$ \\
\hline First & Obs1 $\times$ Obs2 & Concave & $459(59 \%)$ & 0.412 & $<0.0001$ \\
\hline First & Obs1 $\times$ Obs3 & Concave & $465(72 \%)$ & 0.593 & $<0.0001$ \\
\hline First & Obs2 $\times$ Obs3 & Concave & $470(59.8 \%)$ & 0.430 & $<0.0001$ \\
\hline First & Obs1 $\times$ Obs2 & Convex & $464(63.1 \%)$ & 0.381 & $<0.0001$ \\
\hline First & Obs1 $\times$ Obs3 & Convex & $468(74.6 \%)$ & 0.577 & $<0.0001$ \\
\hline First & Obs2 $\times$ Obs3 & Convex & $470(61.9 \%)$ & 0.386 & $<0.0001$ \\
\hline Second & Obs1 $\times$ Obs2 & Concave & $473(71.7 \%)$ & 0.598 & $<0.0001$ \\
\hline Second & Obs1 $\times$ Obs3 & Concave & $468(59.2 \%)$ & 0.418 & $<0.0001$ \\
\hline Second & Obs2 $\times$ Obs3 & Concave & $466(59 \%)$ & 0.425 & $<0.0001$ \\
\hline Second & Obs1 $\times$ Obs2 & Convex & $472(73.3 \%)$ & 0.563 & $<0.0001$ \\
\hline Second & Obs1 $\times$ Obs3 & Convex & $468(62.8 \%)$ & 0.375 & $<0.0001$ \\
\hline Second & Obs2 $\times$ Obs3 & Convex & $464(57.8 \%)$ & 0.337 & $<0.0001$ \\
\hline Obs 1- Observer Obs $2-$ Observer II: Obs-3 Observer III Obs 4- Observer IV Cohen's Kappa
\end{tabular}

The findings of the three surgeons were compared, to assess interobserver reliability. The overall kappa value was fair to moderate (0.337 - 0.598), indicating moderate agreement.

\section{DISCUSSION}

In the present study, we evaluate the reliability of the radiological Watanabe classification, which we used as a standard preoperative routine to foresee any threat, and believe it to be a tool that can assist in pre- and intraoperative planning, and in the decision on whether to skip an abnormal pedicle or change the instrumentation method.

The literature review did not find any studies analyzing the reliability of the radiological Watanabe classification. This is mainly because other authors used another method of classification based on millimetric measurements in the CT.

Sarwahi ${ }^{15}$ describe four types classification: A- a pedicle of more than 4 mm; B- 2 -4 mm of cancellous bone; C- cortical channel $>2 \mathrm{~mm}$; D- cortical or cancellous channel $<2 \mathrm{~mm}$. Watanabe incremented his classification with the mean percentage of cancellous bone inside the pedicle: A- $56 \%$, B-49 \%, C-34 \% and D- 38\%. This is a divergence if you follow the classification description because type $D$ is considered a slit or absent pedicle. We decide to use the visual radiological classification of the pedicular morphology described by Watanabe, without measuring the pedicle or the percentage of cancellous bone, in order to avoid being influenced by previous radiological measures. We believe the main implication of safe instrumentation is the presence of cancellous bone, therefore small differences in millimeters would not compromise our plan.

Incidentally, if using Sarwahi's classification, it would be necessary to measure the pedicle width, or request that this be done in advance by the radiological department, thereby eliminating the practical characteristic of the radiological and visual Watanabe classification.

We did not use MRI, a harmless method, to assess the pedicles. The reason for this is that although previous studies using $M R I^{19}$ to evaluate pedicles have demonstrated that Pedicles $A$ and $B$ are well recognized, with $85 \%$ accuracy, for pedicles $C$ and $D$, the accuracy is too low, with $44 \%$ for $C$ and zero for $D$.

Comparing our interobserver and intraobserver data, we found differences in the literature, with fair to almost perfect Kappa scores (0.34-0.92) for intraobserver agreement and fair to moderate Kappa scores (0.33-0.59) for interobserver agreement. One of the younger observers had the best coherence in the intraobserver comparison, and the most divergent scores in pedicles $\mathrm{C}$ and $\mathrm{D}$ when compared to the literature. ${ }^{15}$

We analyzed 937 thoracic pedicles in our cohort, which had an average age of 16.3 years and a mean Cobb angle of 67 degrees. The cohort was divided in three groups by Cobb magnitude, 40$59^{\circ}, 60-79^{\circ}$ and greater than $80^{\circ}$. Comparing with the Watanabe data, our senior observer found types $A$ and $B$ of $72 \%$ for concave pedicles and $81 \%$ for concave pedicles in the Watanabe study, while the younger surgeons found $68 \%$ and $66 \%$ respectively. Although when comparing to adolescent idiopathic scoliosis (AIS), the results of the Watanabe classification, more close to our data (45 idiopathic scoliosis of 55 patients), the senior observer had $72 \%$ concave pedicles $A$ and $B$ and the Watanabe classification had $74 \%$, with better agreement.

In the Watanabe classification, types A and B were considered normal and easy to insert the screws, with only $18.5 \%$ abnormal concave pedicles, in contrast to $28 \%, 31 \%$ and $33 \%$ of our data. For concave pedicle screws, there is moderate correlation between the findings of our study and those of the Watanabe classification.

The findings for the convex pedicles were more controversial, especially in $\mathrm{C}$ and $\mathrm{D}$ pedicles, for which Watanabe described $1.9 \% \mathrm{C}$ and $\mathrm{D}$ pedicles and in our study, $11 \%$ to $19 \%$, depending on the observer. 
The higher the Cobb angle, the more it can influence the results. An angle of more than $70^{\circ}$ is considered a risk for dysplasia in some studies. Watanabe divided the Cobb angle into three groups: 40-59; $60-79^{\circ}$ and greater than $80^{\circ}$, and found a tendency to decrease in pedicles $A$ and $B$ and increase in $C$ and $D$ as the Cobb angle increases. Although it was not the aim of our study, we found the same tendency between those groups.

The findings of intraobserver and interobserver agreement may jeopardize the reliability of the classification. Although we had fair to moderate agreement in the intra- and interobserver agreement, we expected the results to be more similar to the literature. However, the results of our senior observer were closer to the Watanabe description, so it may be the case that experienced surgeons have higher accuracy.

Our interobserver agreement, when compared to other morphological classifications, was lower than the literature. We believe this is a consequence of the visual classification adopted, because if there were previous millimetric measurement, as in the Sarwahi description, the level of agreement would be less susceptible to error.

Another argument that might explain the difference in the morphological classification of our study could be the morphology of Brazilian pedicle with scoliosis, for which studies are rare and already explained why. In China, ${ }^{20} \mathrm{AIS}$ patients had $25 \%$ of pedicles C and D, higher than Watanabe and Sarwahi studies, closer to our findings.

Compared to the objective Sarwahi classification the difference is even higher; they had $93.8 \%$ of pedicles A and B in the AIS and only $6.2 \%$ of $\mathrm{C}$ and $\mathrm{D}$.

Even in a more precise evaluation, we believe it is not practical, as it would be necessary to spend time measuring, or to request a scan be carried out by the radiological service.
From our perspective, the radiological Watanabe is more clinically similar with the possible difficulties in the preoperative planning and in the intraoperative procedure, as we have a moderate agreement with the original intraoperative Watanabe description. We think that small difference in millimetric measurements or percentage of cancellous bone measures of the pedicle width is not more important than the presence of large or thin cancellous bone.

Although the Watanabe radiological classification has its limitations in regard to interobserver and intraobserver agreement, as shown by our study, we still believe this to be the most suitable classification, as it enables the surgeon him/herself to analyze the presence of cancellous bone, in a practical way. And we believe that this is the most important indicator of potential difficulty when probing a pedicle.

Perhaps if pedicle types A and B were combined into one type, and $C$ and $D$ into another, there would be more agreement and better intraoperative correlation, therefore a new classification is possible.

\section{CONCLUSION}

The intraobserver agreement of the radiological Watanabe classification was fair to almost perfect (kappa 0.34-0.92), and the interobserver agreement was fair to moderate (kappa 0.33-0.59). The agreement with the Watanabe description increased with the surgeon's experience, becoming a reliable form of analysis. The Watanabe classification therefore continues to be an important tool for preoperative evaluation of thoracic pedicles in scoliosis.

All authors declare no potential conflict of interest related to this article.

CONTRIBUTION OF THE AUTHORS: Each author made significant individual contributions to this manuscript. LEA: writing, revision and performing the surgical procedures; LECTS: surgical procedures, data analysis and writing; CC: surgical procedures and writing; RTV: statistical analysis and revision; GV: statistical analysis and revision; $\mathrm{MJ}$ : writing, revision and intellectual concept.

\section{REFERENCES}

1. Hamill CL, Lenke LG, Bridwell KH, Chapman MP, Blanke K, Baldus C. The use of pedicle screw fixation to improve correction in the lumbar spine of patients with idiopathic scoliosis. Is it warranted? Spine (Phila Pa 1976). 1996;21(10):1241-9.

2. Suk SI, Lee CK, Min HJ, Cho KH, Oh JH. Comparison of Cotrel-Dubousset pedicle screws and hooks in the treatment of idiopathic scoliosis. Int Orthop. 1994;18(6):341-6.

3. Yilmaz G, Borkhuu B, Dhawale AA, Oto M, Littleton AG, Mason DE, et al. Comparative analysis of hook, hybrid, and pedicle screw instrumentation in the posterior treatment of adolescent idiopathic scoliosis. J Pediatr Orthop. 2012;32(5):490-9.

4. Lillenqvist $U$. Hackenberg L, Link T, Halm H. Pullout strength of pedicle screws versus pedicle and laminar hooks in the thoracic spine. Acta Orthop Belg. 2001;67(2):157-63.

5. Panjabi MM, O'holleran JD, Crisco JJ, Kothe R. Complexity of the thoracic spine pedicle anatomy. 1997:6(1):19-24.

6. Vaccaro AR, Rizzolo SJ, Allardyce TJ, Ramsey M, Salvo J, Balderston RA, et al. Placement of pedicle screws in the thoracic spine. Part I: Morphometric analysis of the thoracic vertebrae. J Bone Joint Surg Am. 1995;77(8):1193-9.

7. Parent S, Labelle H, Skalli W, Latimer B, de Guise J. Morphometric analysis of anatomic scoliotic specimens. Spine (Phila Pa 1976). 2002;27(21):2305-11

8. Parent S, Labelle H, Skalli W, de Guise J. Thoracic pedicle morphometry in vertebrae from scoliotic spines. Spine (Phila Pa 1976). 2004:29(3):239-48.

9. Liljenqvist UR, Link TM, Halm HF. Morphometric analysis of thoracic and lumbar vertebrae in idiopathic scoliosis. Spine (Phila Pa 1976). 2000;25(10):1247- 53.

10. Hicks JM, Singla A, Shen FH, Arlet V. Complications of pedicle screw fixation in scoliosis surgery: a systematic review. Spine (Phila Pa 1976). 2010;35(11):465-70.

11. Davis CM, Grant CA, Pearcy MJ, Askin GN, Labrom RD, Izatt MT, et al. Is there asymmetry between the concave and convex pedicles in adolescent idiopathic scoliosis? A CT investigation. Clin Orthop Relat Res. 2017;475(3):884-93

12. Claiborne $P$, Mallios A, Taubman K, Blebea J. Endovascular repair of thoracic aortic injury after spinal instrumentation. Journal of Vascular Surgery Cases. 2015;1(4):264-7.

13. Diab M, Smith AR, Kuklo TR. Neural complications in the surgical treatment of adolescent idiopathic scoliosis. Spine (Phila Pa 1976). 2007;32(24):2759-63.

14. Watanabe K, Lenke LG, Matsumoto M, Harimaya K, Kim YJ, Hensley M, et al. A novel pedicle channel classification describing osseous anatomy: how many thoracic scoliotic pedicles have cancellous channels? Spine (Phila Pa 1976). 2010;35(20):1836-42.

15. Sarwahi V, Sugarman EP, Wollowick AL, Amaral TD, Lo Y, Thornhill B. Prevalence, distribution, and surgical relevance of abnormal pedicles in spines with adolescent idiopathic scoliosis vs. no deformity: a CT-based study. J Bone Joint Surg Am. 2014:96(11):e92.

16. Cohen J. A coefficient of agreement for nominal scales. Educ Psychol Measur. 1960;20(1):37-46

17. Cohen J. (1968). Weighted kappa: Nominal scale agreement provision for scaled disagreement or partial credit. Psychol bull. 1968;70(4):213-20.

18. Fleiss JL, Cohen J, Everitt BS. Large sample standard errors of kappa and weighted kappa. Psychol Bull. 1969;72(5):323-7.

19. Sarwahi V, Amaral T, Wendolowski S, Gecelter R, Sugarman E, Lo Y, et al. MRls Are Less Accurate Tools for the Most Critically Worrisome Pedicles Compared to CT Scans. Spine deformity. 2016;4(6):400-6.

20. Huang J, Zhang $P$, Jian $X$, Jiang $H$. The Prevalence and Distribution of Vertebral Pedicles in Adolescent Idiopathic Scoliosis in Chinese people: A Computed Tomography-Based Study of 2958 Vertebral Pedicles. World Neurosurg. 2018;119:e560-7. 